\title{
The Lumber Industry, 1925
}

\section{R. H. COATS, B.A., F.S.S. (Hon.,) F.R.S.C.., Dominion Statistician and R.G. LEWIS, B.Sc.F., Forest Products Statistics; Department of Trade and Commerce, Ottawa}

December 29th, 1926. -... A preliminary report on the lumber industry in Canada during the calendar year 1925, has just been issued by the Forest Products Branch of the Dominion Bureau of Statisties. This report shows inceases in the quantity production of lumber, lath, and shingles, the ehief products of the industry, as well as box shooks, vencer, pickets, staves; spoolwood, and poles. There were decreases in quanintity with prepared pulpwood, sawn ties, mill waste sold for fuel, and heading. Although the production of sawn lumber increased, the average value per thouand feet was less tlian in 1924, and the total value decreased. Other decreases for total value were reportfor shingles, pulpwood, sawn ties, box shooks, mill waste sold, and heading manufactured, while incerases were reported for lath, veneer, pickets, staves, spoolrood, and piles. The total value of all the produets the industry decreased from $\$ 141,929,256$ in 1924 $\$ 133,631,808$ in 1925 , a decrease of 5.8 per cent.

As far as the gross value of production is concerned, the saw-milling industry ralsks fifth among the imrtant industries of Canada, laving fallen from third ece in 1924. Its gross production is now exceeded that of the pulp and paper industry, flour and grist ills, slaughtering and meat packing establishments, d butter and cheese factories. With regard to the Set value of proluction, or the value added by manuEageture, obtained by subtracting the cost of raw materials from the gross value of products, the saw-milling Eindustry comes second only to the pulp and paper industry, witl a net total in 1925 of $\$ 55,412,080$. The Saw-milling industry comes first among Canadian inФdustries with regard to total number of employees; second with regard to wage distribution; and third Ewith regard to capital investment.

The production of sawn lumber in Canada reached $\Psi_{\text {its }}$ maximum in 1911 with a reported ent of $4,918,2(1) 2$ A. ft. b.m. A seconcl peak was reached in 1920 , with E eut of $4,298,80+M$. ft. b.m., followed by a considerable decrease in 1921. Inereases in quantity production Ghave taken place annually since 1921 , with a production of $3,888,920$ M. ft. b.m., in 1925 , valued at $\$ 99,725,519$ as compared to $3,878,942 \mathrm{M}$. ft. in 1924 , valued at $\$ 104$,444,622. The 1925 production represents an increase of 0.2 per cent in quantity, but a decrease of 4.7 per cent in total value. The average value of all kinds of lumber decreased from $\$ 26.93$ per M. ft. in 1924 to $\$ 25.64$ in 1925 , a decrease of 5 per cent.

The production of shingles increased in quantity. but decreased in value, from $3,129,501 \mathrm{M}$. in 1924 , valued at $\$ 10,406,293$, to $3,161,459 \mathrm{M}$. in 1925 , valued at $\$ 10,372,736$.

The preparation of pulpwood, including cutting-up and barking or rossing, is carried on as a side-line in many Canadian saw-mills, and is therefore included as part of the saw-milling industry. Prepared pulpwood comes third in importance, with 706,700 cords, valued at $\$ 9,169,976$, as compared to 814,180 cords, valued at $\$ 11,583,293$ in 1924 . from 1,165,819 M, in 1924, to 1.292 .963 in 1925, and the total value increased from $\$ \overline{5}, 975,253$ in 1924 to $\$ 6,415,927$ in 1925 .

While there were fewer mills in operation in 1925 than in 1!20t, the average proluction per mili was higher. The 2761 mills reporting in 1924 had an average annual output of 1,405 M. ft. b.m., while the 2700 mills reporting in 1925 produced an average of 1,440 II. fi. 'The total number of employees on salaries and wages derreased from 35,494 to 35,458 , and the total pay roll decreased from $\$ 34,783,780$ to $\$ 34,097,006$. The average carnings per employce during the year de areased from $\$ 980$ to $\$ 962$. The cost of fuel used in the industry decreased from $\$ 651.499$ in 1924 to $\$ 5+6$, 025 in 1925 , but the tolal quantity of power employed increased from 28,5,263 h.p. $10,295.246$ h.p. Raw ma terials in this industry, which are on the form of logst bolts and rough coldwoorl, were valued at $\$ 78,219$, ize in 1925 , as compared to $\$ 83.1+1.692$ in 1924 . The value added by manufacture was $\$ 0.0,22.080$, and the total cost of raw materials lormed 58.5 pere cent of the total value of the finished products in 1925, as compared to 58.6 per cent in 1924 .

The ratio of the aost of raw materials to value of products has increased eonsiderably, on the whole. during the last few yours in the lumlier industry, be cause of increases in stumpage values and increases in the cost of logging doe to the longer distances logs must be transportal as the more aloessible supplies of timber are exhansted. 'lhis ratio for the last nine real's is as follows:

$\begin{array}{lllllllll}1917 & \ldots . & 35.1 & 1921 & \ldots . & \ldots . & 49.0 \\ 1918 & \ldots & \ldots & 31.3 & 192.2 & \ldots . & \ldots . & 53.2 \\ 1919 & \ldots & \ldots & 44.7 & 192.3 & \ldots . & \ldots . & 52.4 \\ 1920 & \ldots & \ldots & 49.8 & 1924 & \ldots . & \ldots . & 58.6 \\ & & & & 1925 & \ldots . & \ldots . & 58.5\end{array}$

The capital invested in the industry increased from $\$ 177,480,064$ in 1924 to $\$ 204,134,00: 3$ in 1925 .

British Colmmbia heads the list in the production of sawn lumber and shingles; New Brumswick comes first in latl production; and Quebee is first in the prepara tion of pulpwood. The prodnetion of lumber increased in the provinces of liritisl columbia, Manitoba, Saskatehewan, Alberta, and l'rince Edward Lslanel, and decreased in Ontario, Quebec, New Brunswick, and Nova Scotia.

The figures on which this preliminary report are based are sulpjeet to revision on further examination of the individual reports. The complete, revised statistics of the lumber industry for the calendar year 1925 will be included in the regular annual printed report, which will be available for distribution in a short time. (opies may be secured on appliation to the Doincinion Statistieian, Dominion Bureau of Statistics or to the King's l'rinter, Ottawa, Canada.

The following tables include a summary of the prin cipal statistics of the industry, by provinces, and a summary of the primary and secondary produets of 
Table 1.-Principal Statisties of the Lumber Industry, 1925.

\begin{tabular}{|c|c|c|c|c|}
\hline $\begin{array}{l}\text { Mills } \\
\text { in } \\
\text { opera- } \\
\text { tion }\end{array}$ & $\begin{array}{l}\text { Em- } \\
\text { ployees }\end{array}$ & $\begin{array}{l}\text { Salaries } \\
\text { and wages }\end{array}$ & $\begin{array}{l}\text { Cost of } \\
\text { materials }\end{array}$ & $\begin{array}{l}\text { Gross value } \\
\text { of product }\end{array}$ \\
\hline No. & & & No. & $\$$ \\
\hline $\begin{array}{llllll} & \ldots & \ldots & \ldots & \ldots & \ldots\end{array}$ & 35,458 & $34,097,006$ & $78,219,728$ & $133,631,808$ \\
\hline British Columbia $\ldots . . . . . . . . . . .$. & $1: 3,917$ & $15,938,079$ & $28,871,174$ & $5: 3,069,575$ \\
\hline $\begin{array}{llllllll}\text { Ontario } & \ldots . & \ldots & \ldots & \ldots & \ldots & \ldots & \ldots\end{array}$ & 8,361 & $8,490,771$ & $22,073,392$ & $36,141,672$ \\
\hline 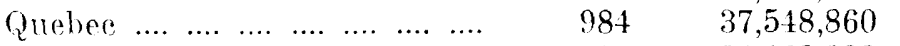 & 6,063 & $4,572,983$ & $14,724,377$ & $22,802,029$ \\
\hline New Brunswick .... ................ & 4,193 & $3.17: 3,6: 31$ & $8,999,292$ & $14,648,407$ \\
\hline Nova Seotia .... ..................... & 1,705 &, 252 & $1,721,767$ & $3,043,069$ \\
\hline $\begin{array}{ccccccc}\text { Manitoba } & . . & \ldots & \ldots . & \ldots & \ldots . & \ldots . .\end{array}$ & 562 & $60+.996$ & $1,119.272$ & $2,427,421$ \\
\hline Alherta ............................ & 468 & 73 & 19 & 996,593 \\
\hline 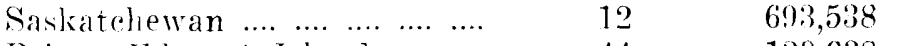 & 220 & $3+346$ & $91: 3$ & $3 \vec{\imath} 1,189$ \\
\hline Prince Edward Istand .... .... & 28 & 12,775 & 72.328 & $1: 1,8,33$ \\
\hline \multicolumn{5}{|c|}{ Table 2.--Summary of Products of the Lumber !ndustry. 1924 and 1925.} \\
\hline \multirow[t]{2}{*}{ Products } & \multicolumn{2}{|c|}{ Quantity } & \multicolumn{2}{|c|}{ Value } \\
\hline & 1924 & 1925 & 1924 & 1925 \\
\hline Total, all products ........................... value only & $\ldots$ & - & $1+1,929,256$ & $1: 33,631,808$ \\
\hline 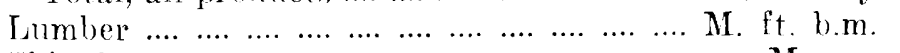 & $3,878,942$ & $3,888,920$ & $104,444,622$ & 99,7 \\
\hline 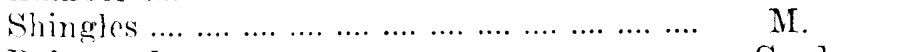 & $3,129,501$ & $3,161,459$ & $10,406,293$ & $10,37^{2}, 736$ \\
\hline 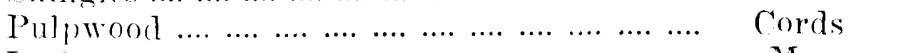 & 814,180 & 706,700 & $11,583,293$ & $?, 160,976$ \\
\hline 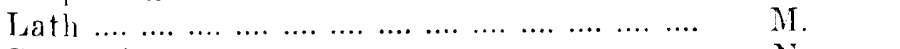 & $1,165,819$ & $1,292,963$ & $5,975,253$ & $6,415,927$ \\
\hline Sawn ties & $5,274,682$ & $5.041,2,56$ & $3,723,712$ & $3,474,9+4$ \\
\hline Box shooks ....................................... & 15,584 & 20,181 & $1,998,688$ & $1,0,55,658$ \\
\hline 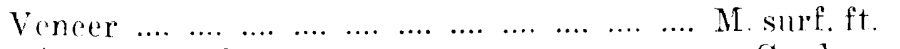 & 17,699 & 21,570 & $841,85 \overline{5}$ & $8 . \overline{4}, 179$ \\
\hline 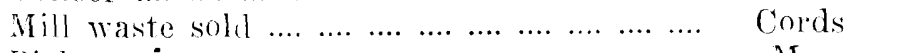 & 331,133 & 286,426 & 821,389 & 746,382 \\
\hline 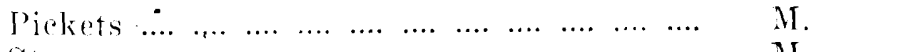 & 19,758 & 36,654 & 567,707 & 592,6667 \\
\hline Staves ........................................... & 23,486 & 34,403 & 256,897 & 339,118 \\
\hline 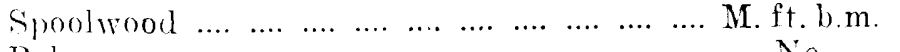 & 2,865 & 4,105 & 101,369 & 167,095 \\
\hline 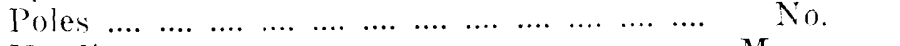 & 38,766 & $39,41: 3$ & 66,364 & $124,8: 38$ \\
\hline 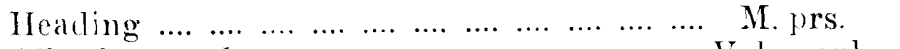 & 1,829 & $1,3,37$ & 174,423 & 124,000 \\
\hline All other products ................................. Value only & - & - & $967,9,91$ & 486,767 \\
\hline
\end{tabular}

\section{Safety First in Logging Camps}

Britisl Colmmbia Loggers Association, of Vancouver, maintains a safety department as part of the regular alctivities. The results have justified the effort to realuce accidents. In the production of 746000,000 feet of logs, 15 fatal accidents resulted. An assessment of ome-half ecnt per thousand feet is made for safety work. The association regularly issues graphic bulletins designed especially to eatch the eye of the logger and instill a ralization of the need for callion at all times. Iajor H. R. Andrews, of the Association, is a firm believer in safety first work.

The Timberman from which we are quoting, has suggested that a bonus system might be very properly indugurated as part of the safoty work, thereby insuring a direct financial return to the key men for the rebuction of aceidents. While lectures, cartoons and safety first committees are to be commended as aldjuncts in carrying on safoty work, nevertheless a clirect financial participation ly the men who are responsible in great measure for prevention of accidents should prove a compelling incentive to exercise constant care. in reducing the accident hazard to the minimum.

logging is as dangerours an occupation as is warfare. There are hazards which are inseparable from the industry. Carelessness on the part of the men is responsible for many avoidable aceidents, and the formman, hooktender, loader and engineer can assist mate. rially through helpful co-operation in reduction of aceidents. Perhaps a direct financial return mighi prove a stimulus in the avoidance of preventable accidents.

The Timberman asks for the opinion of safety first 'mgineers on the subject of payment bolluses as a means of reducing accidents. 